\title{
Analisis Faktor yang Mempengaruhi Kepuasan Pasien di Apotek Rumah Sakit Swasta Karawang
}

\author{
Maya Arfania*, Nono Suryana, Himyatul Hidayah
}

Program Studi Farmasi, Fakultas Farmasi, Universitas Buana Perjuangan Karawang, Jawa Barat, Indonesia

*E-mail: maya.arfania@ubpkarawang.ac.id

(Submit 19/12/2021, Revisi 20/12/2021, Diterima 30/12/2021, Terbit 31/12/2021)

\begin{abstract}
Abstrak
Apotek rawat jalan merupakan salah satu instalasi bagian penting di rumah sakit. Strategi untuk memenangkan persaingan dapat dilakukan dengan cara meningkatkan kualitas pelayanan, salah satu indikator yang paling banyak dipakai untuk mengukur kualitas pelayanan adalah tingkat kepuasan pelanggan. Penelitian ini bertujuan untuk mengetahui faktor yang mempengaruhi tingkat kepuasan pasien di apotek rumah sakit swasta di Karawang. Metode pada penelitian ini menggunakan metode survei dengan pendekatan cross sectional. Alat yang digunakan adalah kuesioner SERVQUAL yang mencakup 5 dimensi service quality (reliability, assurance, tangible, empathy, dan responsiveness ) dengan skala Likert. Metode analisis yang digunakan adalah analisis deskriptif dan uji chi square dengan taraf kepercayaan 95\%. Hasil penelitian menunjukkan pada dimensi reliability sebagian besar pasien merasa puas $(49,2 \%)$, pada dimensi assurance sebagian besar pasien merasa tidak puas $(40,1 \%)$, pada dimensi tangible sebagian besar pasien merasa puas $(53,8 \%)$, pada dimensi Empathy sebagian besar pasien merasa puas $(43,1 \%)$, dan pada dimensi responsiveness sebagian besar pasien merasa puas (41,6\%). Analisis hubungan tingkat kepuasan pasien terhadap 5 dimensi service quality didapatkan p-value 0,01 (reliability); 0,095 (assurance); 0,02 (tangible); 0,08 (empathy); dan 0,026 (responsiveness). Dari hasil tersebut disimpulkan bahwa dimensi reliability, tangible, dan responsiveness merupakan faktor yang mempengaruhi tingkat kepuasan pasien di apotek rumah sakit swasta Karawang .
\end{abstract}

Kata Kunci: Apotek, Kepuasan, SERVQUAL

\section{Pendahuluan}

Tuntutan pasien menyebabkan terjadinya perubahan paradigma yang berorientasi pada pasien (patient oriented) dengan filosofi pharmaceutical care(1). Kualitas pelayanan merupakan hal penting yang harus diperhatikan oleh rumah sakit. Hal ini dapat dilakukan dengan berbagai cara, seperti sikap sopan santun dan ramah karyawan yang berhubungan dengan konsumen dan kemampuannya untuk menyampaikan 
kepercayaan, pelayanan administratif yang cepat dan tepat, layanan produk sesuai perjanjian, tersedianya sarana dan prasarana yang memadai, biaya terjangkau, tepat waktu dan memuaskan bagi pasien ${ }^{(2)}$.

Penelitian yang telah dilakukan sebelumnya melaporkan bahwa terdapat beberapa faktor yang mempengaruhi tingkat kepuasan pasien yaitu karakteristik dan demografi pasien, teori SERVQUAL (reability, responsiveness, tangible, assurance, dan empathy), dan humanitas, aksesbilitas, sumber biaya, dan total biaya yang dikeluarkan(3). Aryani melalui penelitiannya di RSI Ibnu Sina Pekanbaru melaporkan tingkat kepuasan pasien terhadap pelayanan di IFRS tersebut masih rendah dengan nilai gap tertinggi berada pada aspek reliability. Hal ini disebabkan karena antrian yang tidak jelas, sehingga banyak pasien yang merasa kecewa karena merasa seharusnya mendapatkan pelayanan terlebih dahulu(4).

Penelitian yang dilakukan oleh Akbar et al menunjukkan bahwa di Instalasi Farmasi RSD Idaman Banjarbaru mendapatkan skor rata-rata pada dimensi reliability sebesar $86,30 \%$, dimensi responsiveness sebesar $84,45 \%$, dimensi assurance sebesar $84,75 \%$, dimensi empathy sebesar $86,30 \%$, dan dimensi tangible sebesar $84,70 \%$. Pada penelitian ini didapatkan kesimpulan pasien merasa sangat puas dengan pelayanan kefarmasian di RSD Idaman Banjarbaru(5).

Berdasarkan latarbelakang diatas, maka peneliti tertarik untuk melakukan penelitian mengenai tingkat kepuasan pasien terhadap apotek di rumah sakit swasta Karawang menggunakan kuesioner service quality.

\section{Metode}

\section{Alat}

Alat yang digunakan pada penelitian ini adalah lembar kuesioner servqual yang telah diuji validitas dan reliabilitasnya. Analisis data menggunakan SPSS yaitu uji chi square dengan taraf kepercayaan $95 \%$.

\section{Bahan}

Bahan pada penelitian ini adalah data pasien berdasarkan hasil kuesioner.

\section{Prosedur}

Penelitian ini adalah penelitian analitik dengan pendekatan cross sectional yang dilakukan di apotek salah satu rumah sakit swasta di Karawang. Penelitian dilakukan pada bulan Juli sampai Agustus 2020. Untuk mengetahui tingkat kepuasan pasien menggunakan kuesioner SERVQUAL (service quality) yang mencakup 5 dimensi yaitu reliability, assurance, tangible, empathy dan responsiveness. 
Populasi dalam penelitian ini adalah seluruh pasien rawat jalan di apotek rumah sakit swasta Karawang yang mendapatkan resep racikan dari dokter. Pengambilan sampel dilakukan secara total sampling dengan kriteria inklusi yaitu pasien yang bersedia menjadi responden dan pasien yang mendapat resep racikan sedangkan kriteria eksklusi adalah pasien berkebutuhan khusus (tidak bisa berbicara dan mendengar). Jumlah sampel pada penelitian ini adalah sebanyak 65 pasien. Untuk melihat tingkat kepuasan terhadap dimensi service quality digunakan SPSS yaitu uji chi square dengan taraf kepercayaan 95\%. Penelitian ini telah dilengkapi dengan ijin dari komite etik dengan nomor 531/UN6.KEP/EC/2020.

\section{Hasil}

Data demografi pasien pada penelitian ini meliputi beberapa aspek, yaitu jenis kelamin, usia, dan pendidikan terakhir. Karakteristik responden diperlukan untuk melihat sebaran atau variasi populasi yang mungkin akan mempengaruhi hasil penelitian.

Tabel 1. Data demografi responden di apotek rumah sakit swasta Karawang

\begin{tabular}{lcc}
\hline \multicolumn{1}{c}{ Karakteristik } & $\mathrm{f}$ & $\%$ \\
\hline Usia & 8 & 12,3 \\
$<18$ tahun & 40 & 61,5 \\
18-60 tahun & 17 & 26,2 \\
$>60$ tahun & & \\
\hline Jenis Kelamin & 27 & 41,5 \\
Laki-laki & 38 & 58,5 \\
Perempuan & & \\
\hline Tingkat Pendidikan & 8 & 12,3 \\
Belum Sekolah & 27 & 41,5 \\
SMA & 7 & 10,8 \\
D3 & 23 & 35,4 \\
S1 & & \\
\hline
\end{tabular}

Dimensi reliability berkaitan dengan kemampuan perusahaan penyedia jasa dalam memberikan layanan yang dijanjikan kepada pasien secara tepat sejak pertama kali(6). Yang menjadi indikator dalam dimensi ini adalah bukti fasilitas fisik, perlengkapan, pegawai, dan sarana komunikasi(2). 
Tabel 2. Hubungan faktor dimensi reliability (kehandalan) terhadap tingkat kepuasan pasien di apotek rumah sakit swasta Karawang

\begin{tabular}{lccccc}
\hline Reliability & \multicolumn{5}{c}{ Tingkat kepuasan pasien } \\
\cline { 2 - 6 } & $\mathrm{f}$ & Tidak Puas & \multicolumn{4}{c}{ Puas } & P-Value \\
\cline { 2 - 6 } & 4 & $\%$ & $\mathrm{f}$ & $\%$ & \\
\hline Baik & 13 & 6,2 & 32 & 49,2 & 0,010 \\
Sedang & 20 & 16 & 24,6 & \\
\hline
\end{tabular}

Dimensi assurance merupakan penilaian pelanggan terhadap pengetahuan, kesopansatunan, dan kemampuan petugas apotek untuk menumbuhkan rasa percaya pada pelanggan ${ }^{(6)}$.

Tabel 3. Hubungan faktor dimensi assurance (jaminan) terhadap tingkat kepuasan pasien di apotek rumah sakit swasta Karawang

\begin{tabular}{|c|c|c|c|c|c|}
\hline \multirow{3}{*}{ Assurance } & \multicolumn{4}{|c|}{ Tingkat kepuasan pasien } & \multirow[t]{3}{*}{$P$-Value } \\
\hline & \multicolumn{2}{|c|}{ Tidak Puas } & \multicolumn{2}{|c|}{ Puas } & \\
\hline & $f$ & $\%$ & $f$ & $\%$ & \\
\hline Baik & 26 & 40 & 10 & 15,4 & 0,095 \\
\hline Sedang & 23 & 35,4 & 6 & 9,2 & \\
\hline
\end{tabular}

Dimensi tangible merupakan penilaian pelanggan terhadap penampilan dan fasilitasfasilitas fisik yang ada di apotek ${ }^{(6)}$.

Tabel 4. Hubungan faktor dimensi tangible (bukti langsung) terhadap tingkat kepuasan pasien di apotek rumah sakit swasta Karawang

\begin{tabular}{|c|c|c|c|c|c|}
\hline \multirow[t]{3}{*}{ Tangible } & \multicolumn{4}{|c|}{ Tingkat kepuasan pasien } & \multirow[t]{3}{*}{$P$-Value } \\
\hline & \multicolumn{2}{|c|}{ Tidak puas } & \multicolumn{2}{|c|}{ Puas } & \\
\hline & $f$ & $\%$ & $f$ & $\%$ & \\
\hline Baik & 1 & 1,6 & 35 & 53,8 & 0,002 \\
\hline Sedang & 8 & 12,3 & 21 & 32,3 & \\
\hline
\end{tabular}

Dimensi empathy adalah penilaian pelanggan mengenai bagaimana perhatiaan dan kepedulian petugas apotek dalam melayani pelanggan ${ }^{(6)}$.

Tabel 5. Hubungan faktor dimensi empathy (empati) terhadap tingkat kepuasan pasien di apotek rumah sakit swasta Karawang

\begin{tabular}{|c|c|c|c|c|c|}
\hline \multirow[t]{3}{*}{ Empathy } & \multicolumn{4}{|c|}{ Tingkat kepuasan pasien } & \multirow[t]{3}{*}{$P$-Value } \\
\hline & \multicolumn{2}{|c|}{ Tidak puas } & \multicolumn{2}{|c|}{ Tidak puas } & \\
\hline & $f$ & $\%$ & $f$ & $\%$ & \\
\hline Baik & 8 & 12,3 & 28 & 43,1 & 0,088 \\
\hline Sedang & 14 & 21,5 & 15 & 23,1 & \\
\hline
\end{tabular}


Dimensi responsiveness adalah penilaian pelanggan terhadap kemampuan petugas apotek membantu dan memberikan pelayanan yang cepat dan tepat kepada pelanggan dengan penyampaian yang jelas ${ }^{(6)}$.

Tabel 6. Hubungan faktor dimensi responsivness (cepat tanggap) terhadap tingkat kepuasan pasien di apotek rumah sakit swasta Karawang

\begin{tabular}{|c|c|c|c|c|c|}
\hline \multirow[t]{3}{*}{ Responsiveness } & \multicolumn{4}{|c|}{ Tingkat kepuasan pasien } & \multirow[t]{3}{*}{$P$-Value } \\
\hline & \multicolumn{2}{|c|}{ Tidak puas } & \multicolumn{2}{|c|}{ Puas } & \\
\hline & $f$ & $\%$ & $f$ & $\%$ & \\
\hline Baik & 9 & 13,8 & 27 & $\overline{41,6}$ & 0,026 \\
\hline Sedang & 14 & 21,5 & 15 & 23,1 & \\
\hline
\end{tabular}

\section{Pembahasan}

Pada tabel 1 menunjukkan responden pada penelitian ini mayoritas berusia di rentang 18-60 tahun sebanyak 40 pasien, yang berusia $>60$ tahun sebanyak 17 pasien, dan yang berusia $<18$ tahun sebanyak 8 pasien. Responden pada penelitian ini didominasi dengan perempuan sebesar 38 pasien. Sedangkan responden dengan jenis kelamin laki-laki sebesar 23 pasien. Tingkat pendidikan responden paling banyak adalah SMA sebesar 27 pasien. Sedangkan responden yang S1 sebesar 23 pasien, D3 sebesar 7 pasien, dan belum sekolah sebesar 8 pasien.

Pada penelitian ini sebagian besar pasien merasa puas pada dimensi reliability yaitu sebesar 32 pasien $(49,2 \%)$ (tabel 2$)$. Hal ini disebabkan karena pasien merasa puas dengan pelayanan yang diberikan oleh apotek. Selain itu, waktu tunggu pelayanan apotek telah sesuai dengan standar sasaran mutu rumah sakit pada unit apotek rawat jalan yaitu maksimal 30 menit. Penelitian ini sejalan dengan penelitian Asuti dimana pada dimensi reliability pasien merasa puas dengan pelayanan petugas di apotek rumah sakit UNS ${ }^{(7)}$ Pengujian menggunakan chi-square mendapatkan $p$-value sebesar $0,010(<0,05)$, yang berarti dimensi reliability merupakan faktor yang mempengaruhi tingkat kepuasan pasien di apotek rumah sakit swasta Karawang .

Supriyanto dan Ernawati mengatakan bahwa yang menjadi indikator dalam dimensi assurance adalah informasi mengenai penyakit, informasi mengenai tindakan, dan prognosis penyakit(8). Dari tabel 3 diketahui bahwa pada penelitian ini pasien merasa tidak puas pada dimensi assurance sebesar 26 pasien (40\%). Hal ini disebabkan menurut penilaian pasien, petugas Apotek kurang dalam memberikan pelayanan informasi obat dengan baik dan kurang dalam memberikan pelayanan yang bermutu sesuai harapan pasien. Pengujian menggunakan chi square didapatkan $p$ value 0,095 yang artinya dimensi assurance bukanlah merupakan faktor yang berpengaruh terhadap kepuasan pasien di Apotek Rumah Sakit Swasta Karawang.

Pada tabel 4 nampak dimensi tangible bernilai baik dan sebesar 35 pasien $(53,8 \%)$ yang mengisi kuesioner merasa puas. Hal ini disebabkan karena petugas apotek menjaga kerapihan seragam yang dikenakan dengan baik sehingga memberikan. 
kenyamanan bagi yang melihatnya. Selain itu apotek di rumah sakit swasta Karawang memiliki ruang tunggu yang bersih dan dilengkapi dengan fasilitas-fasilitas seperti kursi, AC, dan TV yang menambah kenyamanan pasien. Hasil penelitian ini sejalan dengan penelitian yang dilakukan oleh Yudanisa et al dimana pasien yang datang ke salah satu Rumah Sakit Swasta di Bandung merasa puas dengan dimensi tangible sebesar $69,90 \%$. Pasien merasa puas dengan kondisi lingkungan yang bersih dan penataan ruangan yang baik sehingga menciptakan rasa nyaman selama menunggu obat(9). Uji chi square menunjukkan hasil $p$ value sebesar 0,02 yang berarti dimensi tangible merupakan faktor yang mempengaruhi tingkat kepuasan pasien di Apotek Rumah Sakit Swasta Karawang.

Pada penelitian ini sebanyak 28 pasien $(43,1 \%)$ merasa puas pada dimensi empathy (tabel 5). Hal ini menunjukkan bahwa petugas Apotek sudah menunjukkan perhatian dan melayani pasien dengan sepenuh hati. Hasil serupa dilaporkan oleh Yudanisa et al melalui penelitiannya dimana sebanyak $77,43 \%$ responden merasa puas dengan perhatian dan keramahan petugas kepada pasien. Selain itu petugas juga berkomunikasi dengan baik sehingga mudah untuk dipahami oleh pasien(9). Uji chi square pada dimensi empathy mendapatkan $p$-value sebesar 0,088 sehingga disimpulkan dimensi empathy bukanlah merupakan faktor yang mempengaruhi tingkat kepuasan pasien di Apotek Rumah Sakit Swasta Karawang.

Pada tabel 6 nampak bahwa mayoritas pasien merasa puas pada dimensi responsiveness (cepat tanggap) yaitu sebesar 27 pasien $(41,6 \%)$. Hal ini menunjukkan bahwa menurut pasien petugas Apotek telah memberikan pelayanan yang baik kepada pasien dan cepat tanggap dalam menghadapi keluhan pasien. Pristiyantoro et al melalui penelitiannya melaporkan hal serupa, dimana sebanyak $90,7 \%$ pasien merasa puas oleh pelayanan tepat dan cepat yang dilakukan oleh petugas(10). Hasil pengujian chi square didapatkan $p$-value sebesar 0,026 . Hasil tersebut menunjukkan bahwa dimensi responsiveness merupakan faktor yang mempengaruhi tingkat kepuasan pasien terhadap Apotek di Rumah Sakit Swasta Karawang.

\section{Kesimpulan}

Berdasarkan hasil penelitian yang dilakukan, dimensi reliability, tangible, dan responsiveness merupakan faktor yang mempengaruhi tingkat kepuasan pasien di Apotek Rumah Sakit Swasta Karawang dengan p-value masing-masing adalah 0,010; 0,002; dan 0,026.

\section{Daftar Pustaka}

1. Addin Q, Marchaban M, Sumarni S. Analisis GAP Kualitas Pelayanan dengan Kepuasan Pasien di Instalasi Farmasi RSU PKU Muhammadiyah Delanggu Menggunakan Metode SERVQUAL. Maj Farm [Internet]. 2021 Apr 28 [cited 2021 Oct 
2. Tjiptono F. Prinsip-prinsip Quality Service. Yogyakarta: Pemasaran Industri Kesehatan Yogyakarta: Andi; 2014.

3. Suharmiati; Budijanto D. Analisis Faktor-Faktor Yang Mempengaruhi Tingkat Kepuasan Responden Pengguna Rawat Jalan Rumah Sakit Pemerintah di Indonesia. Bul Penelit Sist Kesehat. 2007;10(2).

4. RichaAryani, Fina; Husnawati, Husnawati; Muharni, Septi; Mutia LA. Analisa Kepuasan Pasien Rawat Jalan Terhadap Kualitas Pelayanan Di Instalasi Farmasi Rumah Sakit Islam Ibnu Sina Pekanbaru | Aryani | PHARMACY: Jurnal Farmasi Indonesia (Pharmaceutical Journal of Indonesia). J Pharm [Internet]. 2015 [cited 2021 Oct 6];12(1):101-12. Available from: http://jurnalnasional.ump.ac.id/index.php/PHARMACY/article/view/821

5. Akbar DO, Handayani GD, Putri AN. Gambaran Tingkat Kepuasan Pasien BPJS Rawat Jalan Terhadap Pelayanan Kefarmasian di Instalasi Farmasi RSD Idaman Banjarbaru Tahun 2019. J IIm Ibnu Sina [Internet]. 2020 Mar 30 [cited 2021 Oct 6];5(1):108-16. Available from: http://e-jurnal.stikesisfi.ac.id/index.php/JIIS/article/view/396

6. Harto B. Analisis Tingkat Kepuasan Pelanggan Dengan Pendekatan Fuzzy Servqual Dalam Upaya Peningkatan Kualitas Pelayanan. J TEKNOIF. 2015;3(1):20-3-.

7. Kusuma Astuti N, Wisnu Kundarto dan. Analisis Kepuasan Pasien BPJS Rawat Jalan Terhadap Pelayanan Instalasi Farmasi Rumah Sakit UNS. JPSCR J Pharm Sci Clin Res [Internet]. 2018 Oct 9 [cited 2021 Dec 17];3(2):84-92. Available from: https://jurnal.uns.ac.id/jpscr/article/view/22162

8. Supriyanto, Supriyanto; Ernawaty E. Prinsip Prinsip Quality Service. Yogyakarta: Pemasaran Industri Kesehatan Yogyakarta: Andi; 2010.

9. Yudanisa P, Rachmi A, Yunus A, Romadhona N, Susanti Y. Tingkat Kepuasan Pasien Peserta Badan Penyelenggara Jaminan Sosial terhadap Mutu Pelayanan Farmasi di Instalasi Rawat Jalan. J Integr Kesehat dan Sains [Internet]. 2019 Jul 31 [cited 2021 Oct 6];1(2):174-8. Available from: https://ejournal.unisba.ac.id/index.php/jiks/article/view/4350

10. Pristiyantoro, Pritiyantoro; Dinar K. Tingkat Kepuasan Pasien BPJS Terhadap Pelayanan Kefarmasian di Apotek Kimia Farma Akses UI Kota Depok. J Kefarmasian. 2021;8(1):18-31 